\title{
From what types of government should poor countries accept what types of Aid?
}

\section{by Terry Byres*}

Two broad approaches are possible in commenting upon Dudley Seers's paper. One can accept the terms of his argument and discuss his facts, his logic and his conclusions; or one can reject the basis of his position, dispute his underlying assumptions and pose a different set of questions. If I were following the former procedure there are several points with which I would take issue. Thus, over primary education (p.10) I would be far less sanguine, especially over its likely content (which is unlikely to raise the level of political consciousness) and more especially if I were concerned to stem the tide of migration to the cities (p.10); over the so-called rural-urban imbalance (p.10) I would argue that (in India at least) the scales need tipping the way of the cities, that the net resource flow has been from the cities to the countryside (Michael Lipton notwithstanding), and that this needs to be reversed; over the role of experts (pp.11-12) I would be considerably more unhappy; ${ }^{1}$ and so on. I shall, however, follow the 1 atter approach. I have been asked to be brief and I shall confine myself, therefore, to bare essentials. I shall make my points more or less without accompanying qualifications and in a deliberately provocative fashion.

My first objection to the paper is summed up in the alternative title which I have placed above these notes. Dudley Seers's question has implicit in it the assumption that aid has the power to promote 'development', and the thrust of his argument is that whether or not this power is used depends upon the nature of the government in the receiving country. The way I have posed the question suggests that aid may have no such inherent power and forces one to look more closely than Seers does at the motives for and effects of aid. It must always be stressed, at the risk of labouring the point, that the overwhelming motive behind the $\star$ T.J. Byres is a Fellow at the School of Oriental and African Studies of the University of London.

1 On experts and on much of what I say below I go into in greater detail in an article elsewhere; "The White Man's Burden in a NeoColonial Context", in T.J. Byres (ed.), Foreign Resources and Economic Development, (Frank Cass, 1972). 
giving of aid is the desire to serve the economic and/or political interests of the donor country. It may be held that, nonetheless, 'development' will ensue if an appropriate kind of government is in power in the poor country (Seers appears to reason so). This I would dispute. More precisely, the kind of 'development' likely to be generated by an influx of aid will be undesirable because of the nature of the government in the donor country. We know in detail that dependence upon aid is used by donor countries and by international organisations as $a$ means of bringing pressure to bear upon poor countries to move in specific directions. Teresa Hayter simply revealed in print a little of what was already known, though even that $1 i t t l e$ was enough to bring the wrath of the World Bank and others upon her head. ${ }^{1}$ Seers is correct when he states (p.7) that 'all aid constitutes interference'. But, by ignoring the true nature and extent of that that interference, he by-passes the central point that the net effect of aid is to distort and to stifle efforts to develop: by forcing unnecessary devaluations, by attempting to make poor countries more willing and more pliable hos ts to foreign capital, by insisting upon greater scope for domestic private enterprise etc. etc. etc. The answer to the first half of the question posed, then, is: poor countries should accept aid only from governments and organisations which will not at tempt to influence their priorities. Not many would qualify and the second part of the question would become redundant.

My second objection derives from a further underlying assumption (obvious also in, for example, the Pearson Report). In a nutshell this is that it is improper to contemplate communist political systems in those underdeveloped countries in which they do not exist. At the outset Seers argues that development is a moral concept: involving a reduction in poverty, which must encompass a reduction in unemployment and a reduction in inequality. I agree. His major recommendation is that only those governments who promote such ends should receive aid. But nowhere does he give examples of such governments (he specifies only the patently 'bad' ones, like those of Bolivia, Greece and South Vietnam - p.11). He observes (p.6) that in the 1960's in Latin America, 'high growth rates have frequentily been accompanied by increasing inequality and unemployment'. But where, in Latin America, is the closest approximation to development, as morally construed, to be found? Surely, in Cuba, even if ideals and achievements have diverged. If one asks the same question in the Asian context, surely Mainland China is the country which approaches the ideal most closely, whatever the upheavals and difficulties experienced. Now, to assume that such communist 1 Teresa Hayter, Aid as Imperialism (London, 1971). 
solutions must not be considered possible or desirable is valid for most aid-giving governments (including the Soviet Union, which has never been terribly keen on actively encouraging revolution elsewhere). And it is probably also valid for those social scientist who give advice to such governments in the hope that it will be accepted. It is not, however, valid for all social scientists. Those who do not advise governments are free - indeed, have a duty - to contemplate all alternatives. A further answer to the initial question, then, might be: do not accept aid from those whose primary aim is to prevent revolution.

My third objection is closely related to the previous one. Seers is too intelligent and too sensitive to ignore such considerations. My quarrel with him is that he equates the contemplation of political and social alternatives with a crude and thoughtless advocacy of 'revolution'. He argues that those who attack aid because it prevents revolution 'take on.... a fearful responsibility...... laying down that it is desirable for people to suffer indefinitely and to undergo the horrors of an eventual revolution, often without enquiring whether the preconditions for this exist (including the existence of a substantial and experienced revolutionary organisation)' (p.9). No doubt there are those who proceed in such an unsophisticated fashion, just as the aid lobby has its share of slogan-chanters. If, indeed, the case for 'revolution' were put in the manner portrayed by Seers it would deserve to be rejected. But it is not. His portrayal is something of a caricature. Only a political cretin would ignore whether or not preconditions exist and the need for organisation (one must, of course, admit that many economists are political cretins, though not necessarily those political economists who participate in the argument over revolution). Then, on the question of 'fearful responsibility', one asks: is it any less of a 'fearful responsibility' to actively support policies of festina lente which allow grinding poverty to continue unabated? Seers's solution would be to cut off aid (or perhaps allow aid for primary education and experts in general, as if he were God, though one is left wondering precisely which governments he would deprive. (Would India, where poverty has manifestly not diminished and where unemployment has increased significantly in the 1960 's, be regarded as an offending country)? I would rather take a chance on revolution, if I were God.

My first conclusion - that poor countries should reject aid as well as being horrifying to many may also appear totally unrealistic. Similarly what I have had to say about contemplating alternatives and revolution may seem visionary. After all, few among the poor countries are going to turn down aid, few will 
be put off by counter-revolutionary motivation, and few are ripe for revolution. Absolutely so. I am no more unrealistic than Professor Seers, however. He is as unlikely to be listened to by aid-givers as I am to be heeded by aid-receivers. Economisţs do not formulate aid policy and foreign intellectuals do not make revolutions. Happily, this does not prevent them from stating their view of reality or analysing the implications of particular courses of action. 